\title{
Holy Stimulant of Lord Shiva Becomes Unholy and Curse Stimulant in Tripura
}

\section{Tapasi Bhattacharjee*}

Guest Lecturer in the Department of Human Physiology of Women's College, Agartala, Tripura (West), India

*Corresponding Author: Tapasi Bhattacharjee, Guest Lecturer in the Department of Human Physiology of Women's College, Agartala, Tripura (West), India.
Received: February 21, 2020

Published: March 11, 2020

(c) All rights are reserved by Tapasi

Bhattacharjee.

\begin{abstract}
Cannabis (marijuana/ganja), is the most commonly used addicted substance in Tripura after alcohol and tobacco. It is a psychoactive drug that contains tetrahydrocannabinol (THC) responsible for it's recreational effects. It alters perception. Vedas, holy scripts of Hindu religion explained it's beneficial effects on health. But, nowadays, for it's recreational effects, it becomes the most commonly used illegal drug in the world as well as in Tripura. To protect the young population of Tripura, the Government of Tripura have taken strong steps against it's cultivation and smuggling. Destruction of orchards of cannabis, the food of Lord Shiva in Tripura becomes daily routine of Government of Tripura. Unfortunately, the higher personalities of Government of Tripura totally overlooking that it is used for medicinal purposes in the world from ancient periods. They are unable to think that to inhibit any destruction another destruction is not the solution. So, time have come to us to think again and take proper steps to protect both young population and cannabis (marijuana/ganja) in Tripura.
\end{abstract}

Keywords: Cannabis; Marijuana; Ganja; THC; WHO; Hinduism; Recreational; Lord Shiva

\section{Introduction}

"I am evil. I am good. I am in chillum. I was also in diet of Lord Shiva. Do you know me? I am sweet medicine or addicted substances (ganja/bhang)". This modern age is the age of Science and Technology. In this modern era, the food of Lord Shiva, one of the principal deities of Hinduism turns into the "life ending" substances for the world. Almost, 147 million people of the world $(2.5 \%$ of the world's population) uses cannabis or marijuana or ganja. According to the World Health Organization (WHO), the most extensively cultivated, trafficked and addicted illicit substance is cannabis or marijuana or ganja is the world. It is widely used in the adolescent period of human life. The young adult men use cannabis more than adult young women. The recreational and therapeutic use of cannabis or marijuana or ganja promote the "harmless" nature of it, although it's acute and chronic intoxication can occur [1-4].

Wants, likes and dislikes of every individual change our society rapidly. In our globalized world, free movement of people, goods and money open new opportunities for earning. These dynamic transitions also increase various physiological and psychological stresses on every individual of our society. Lust for more money along with physiological and psychological stresses, many people choose a new way in their lives i.e., intoxication. The traditional drugs along with new synthetic drugs are used for intoxication by modern people.

Like other parts of India, the habits of cannabis addiction and abuse are common in the youths of Tripura. The most popular drugs used by the youths, women and children of Tripura are al- cohol, yaba, ganja (cannabis), corex, phensedly, zecoff, dendrite, heroin and brown sugar [5].

Use of drug is still a sporadic, recreational, exploratory activity. Every addictive or abused substance has both adverse and good effects on us. The tetrahydrocannabinol in marijuana or cannabis has various psychological and physiological effects on the human body like euphoria and anxiety [6]. Painkiller, marijuana reduces inflammation and nausea in people undergoing chemotherapy [7].

This review paper highlights the scenario of strong steps taken by the Government of Tripura to begin a new era in Tripura i.e., "Addiction free Tripura".

\section{Cannabis-feeling of relaxation}

Cannabis is a group of three plants, Cannabis sativa, Cannabis indica, and Cannabis ruderalis with psychoactive properties. The dry flowers, leaves, stems of these plants are used most commonly as illegal drug. This drug is known as weed or pot or marijuana. This psychoactive drugs are used for medical or recreational purposes. The primary psychoactive component of it is tetrahydrocannabinol [8].

The menu in diet of Hindu God "Lord of Bhang" becomes the intoxicating drug "cannabis":

" To the five kingdoms of the plants, which Soma rules as Lord we speak, darbha, bhang, barley, mighty power: may these deliver us from woe" - Atharva Veda; Book 8,7; Verse 20. 
According to the Vedas, cannabis was one of five sacred plants. A fairy godmother lived in its leaves. As a source of happiness, joygiver, liberator, it provides anybody constantly feelings of delight and loss of fear from ancient time.

The cannabis bloomed in India under the protection of the sacred Scriptures- the Vedas from earlier period. There was a myth about the birth of cannabis. When gods and demons swirled the ocean, nectar (Amrit) and poison (Vish or Halahala) arrived in two different pitcher. A battle began between gods and demons for want of nectar. The gods won the battle. Few drops of nectar poured out and sprinkled on the earth. These drops of nectar converted into supernaturally powerful cannabis plant. The released Halahala was so powerful that might destroy all the creation. Then
Lord Shiva consumed the Halahala to protect the universe and known to all as "Neelkanth". After that Lord Shiva was cool down by offering bhang.

Once, Lord Shiva, god of destruction in Hinduism, after hot argument with his wife Parvati, goddesses of power, left home and wandered here and there in the Himalaya. Being tired from aimless wandering, anger and fatigue, he felt asleep under a tree. He noticed an attractive plant after completion of his sleep. He tasted the leaves of the plant from curiosity which changed his mood. His feeling of anger was changed into feeling of happy. Then he included it into his daily diet and he became known as "lord of bhang" [9].

Different addictive varieties of cannabis

\begin{tabular}{|c|c|c|c|c|c|c|c|}
\hline Sl.no. & $\begin{array}{l}\text { Different } \\
\text { cannabis }\end{array}$ & Source & Colour & Key ingredients & Class & $\begin{array}{c}\text { Route of } \\
\text { administration (ROA) }\end{array}$ & $\begin{array}{c}\text { Targeted body } \\
\text { system }\end{array}$ \\
\hline 1. & Marijuana & $\begin{array}{l}\text { Dry leaves, flowers, } \\
\text { stems, and seeds } \\
\text { from the Cannabis } \\
\text { sativa or Cannabis } \\
\text { indica plant. }\end{array}$ & Green & \multirow[t]{5}{*}{$\begin{array}{c}\Delta \text { 9-etrahydro- } \\
\text { cannabinol, } \\
\text { cannabidiol, } \\
\text { cannabinol, } \\
\text { tetrahydrocan- } \\
\text { nabivarin }\end{array}$} & \multirow[t]{5}{*}{$\begin{array}{l}\text { Depressant } \\
\text { or halluci- } \\
\text { nogen or } \\
\text { stimulant. }\end{array}$} & Smoking. & \multirow[t]{5}{*}{$\begin{array}{c}\text { Central nervous } \\
\text { system (CNS) } \\
\text { and peripheral } \\
\text { nervous system } \\
\text { (PNS). }\end{array}$} \\
\hline 2. & $\begin{array}{l}\text { Hashish } \\
\text { (Hash or } \\
\text { Charas) }\end{array}$ & Dry cannabis resin. & $\begin{array}{l}\text { Light } \\
\text { brown to } \\
\text { almost } \\
\text { black. }\end{array}$ & & & Smoking. & \\
\hline 3. & Hash oil & $\begin{array}{c}\text { It is obtained by } \\
\text { extracting THC from } \\
\text { Hasish or Marijuana } \\
\text { in oil }\end{array}$ & $\begin{array}{l}\text { Clear pale } \\
\text { yellow, } \\
\text { reen, } \\
\text { brown and } \\
\text { black } \\
\end{array}$ & & & $\begin{array}{l}\text { Smoking and consumed } \\
\text { orally. }\end{array}$ & \\
\hline 4. & Ganja & $\begin{array}{l}\text { Buds and flowering } \\
\text { top of female can- } \\
\text { nabis plant }\end{array}$ & Rust-green & & & Smoking. & \\
\hline 5. & Bhang & $\begin{array}{l}\text { Dry large leaves and } \\
\text { stem of cannabis } \\
\text { plant. }\end{array}$ & Dark green. & & & $\begin{array}{l}\text { Mixing with food items } \\
\text { and take orally. }\end{array}$ & \\
\hline
\end{tabular}

Table 1: Sources, colours, key ingredients, classes, route of administration and targeted human body organs of different varieties of cannabis [10].

\section{Effects of cannabis on human health}

Cannabis shows adverse as well as beneficial effects on the health of cannabis addicted persons.

\section{Adverse effects}

The adverse effects of marijuana/cannabis arise after immediate and long-term use of it.

- Short-term effects: The short-term effects of marjuina/ cannabis (ganja/bhang) are feeling of relaxation, shortterm memory problems, severe anxiety like fear, psychosis, panic, hallucinations, loss of sense of personal identity, increased heart rate (risk of heart attack), increased risk of stroke, problems with coordination, sexual problems in male [11].

- Long-term effects: The long term effect of Marijuana/cannabis are problem in memory, problem in concentration, problem in intelligence (IQ), problem in ability to think and make decisions, bronchitis, lung infections, chronic cough and increased mucus build-up in the throat [12].

\section{Beneficial effects}

It provides relief in chronic pain, improves lung capacity, helps in lose weight, regulates and prevents diabetes, helps in treatment of depression and anxiety, helps children with autism to control 
their violent mood, regulates and controls seizures, helps strengthen the bone in the process of healing, provides relief to individuals with glaucoma, helps to alleviate anxiety, uses as creams and balms in arthritis, uses for the treatment of inflammatory bowel diseases, causes relief in Crohn's disease or ulcerative colitis, reduces tremors, pain and promotes sleep during the treatment of Parkinson's disease [13].

\section{Recognition of cannabis as medicine}

According to federal law the possession of cannabis is illegal in the United States, except approved research settings. In 2019, in the United States, 34 states had legalized some form of cannabis and its recreational use [14]. Cannabis is not approved by the FDA for the treatment of any cancer-related symptom or side effect of cancer therapy and other medical condition. But Two cannabinoids (dronabinol and nabilone) are approved by the FDA for the treatment of nausea and vomiting caused by chemotherapy in patients who have not responded to antiemetic therapy [15]. Nabiximols, a drug is still under clinical trials in US for identifying it's medicinal functions. The drug- HU-308 reduces dyskinesias, a side effect from years of treatment for Parkinson's disease [16].

\section{Geographical position of Tripura}

Tripura, the third-smallest hilly state in North Eastern India is surrounded by the foreign country Bangladesh to the north, south and west and the Indian states, Assam and Mizoram to east. It Spreads over 10,491.69 km2 (4,050.86 sq mi). It extends from $22^{\circ} 56^{\prime} \mathrm{N}$ to $24^{\circ} 32^{\prime} \mathrm{N}$, and $91^{\circ} 09^{\prime} \mathrm{E}$ to $92^{\circ} 20^{\prime} \mathrm{E}$ [14]. It is reachable by national highways passing through the Karim Ganj district of Assam and Mamit district of Mizoram [17].

\section{The routes of cannabis smuggling}

Almost all parts of west, east, north and south Tripura are under the black grip of addiction. Sonamura, Motinagar, Kamalnagar, Kalamchowra, Boxanagar and other villages in the India- Bangladesh border areas of Sipahijala district, $60 \mathrm{~km}$ from Agartala are the dream land for cannabis cultivation and smuggling. Tripura is the corridor of Northeast for the illegal addicted substance [18].

- The border areas like Indo- Myanmar border, Indo-Bangladesh border and Tripura Mizoram border control the drug smuggling in Tripura, Manipur, Mizoram, Myanmar and Bangladesh. The dry cannabis leaves of Tripura are smuggled to Bangladesh, Middle East countries, Afghanistan and few provinces of Pakistan from Tripura. The promising markets for cannabis of Tripura are Assam, West Bengal, Bihar, Uttar Pradesh and Karnataka from Tripura from 2016 [19].

Most of the medical shops in Agartala, Udaipur, Amarpur, Sabrum, Khowai, Kailasahar, Dharmanagar, Damchhara are openly selling synthetic drugs. The roads connected Maharajganja bajar,
Netaji Chowmahani, Motorstand, Kaman Chowmahani, Battalla of Agartala are the main way of drug trafficking within the town. The small stores and fast food stores Battala, Motorstand and G.B. Bazar supply cannabis and other drugs [20].

\section{Causes of cannabis addiction and abuse in Tripura}

The major causes of cannabis addiction and abuse in Tripura are easy availability of cannabis, previous "Blind" Left Government converted the rubber cultivation to cannabis cultivation in Tripura, new highest Profitable business, easiest earning option for refugees, personal curiosity, to feel good, to feel better, to do better, religious causes, influence of Peer Group, impact of culture and custom, urbanization and unemployment, lack of proper parental supervision, parental pressure, childhood trauma, parental substance use, employed mother, thoughts and beliefs of people, emotionally weak persons, the ins and outs in competition among colleagues, realities of life, excessive attention seeking behaviour, unawareness, glamour of the life and genetic factors [21].

The anti-drug activity of the State Government causes breakdown of cannabis business and economy of Tripura

The situation of cannabis plantation and smuggling had changed drastically from 2018, after the coalition Government led by Bharatiya Janata Party (BJP) and Indigenous Peoples Front of Tripura (IPFT) took the responsibility of the state on March 9, 2018. During campaign in Assemble election in Tripura in 2018, the BJP promised to the people of Tripura to take action against the drug traders in its Vision Document. After several stringent actions of the State Government against addiction in Tripura, cannabis growers now face severe livelihood crisis, people leaving the state in search of jobs. The economy of Tripura is adversely affected. A great section of people whose lives depend on the earning from the cannabis becomes jobless and moneyless. They are unable to earn minimum for their livelihood. Finance Minister Jishnu Debbarma told "not everything can be looked through the economic prism and the crackdown was for the greater good. Yes, people are suffering, but we are making sure we look after them". Most of the cannabis plantations and businesses have now converted to rubber plantations and businesses. The wages from rubber plantations and businesses are significantly lower than the cannabis plantations and businesses. "For ganja, we got Rs 300-Rs 400 a day, for rubber it is Rs 100-Rs 150", said a young tribal man [22].

\section{"Addiction free state"- Sri Biplab Kumar Deb, Chief Minister of Tripura}

To fulfil the vision "Tripura- An addiction free State" of Chief Minister of Tripura, Sri Biplab kumar Deb the State Government take fruitful steps like:

- During anti-drug operation police identify a strong nexus among a class of police persons, smugglers and some local political leaders. In the anti-drug operation, police arrested many people including police persons, smugglers and peddlers involve in the drug peddling rackets. 
- The police recovered dry cannabis, destroyed orchads of cannabis and seized other drugs like brown sugar, heroin, alcohols, phensidyl, yaba and other synthetic tablets.

- Anti-drug awareness campaigns in the schools and colleges.

- Anti-drug awareness campaign vehicle has been travelling from place to place.

- Anti-drug street drama, dance and song play an important role to show the dangerous effects of drugs on human health and society.

- The government will return farmers in gainful cultivation of cash crops by giving them incentives. The youths will employed in self-help schemes, especially dairy, poultry and animal husbandry [19].

\section{Suggestions}

- Legalization of cannabis orchards for research and medicinal purposes without destroying these medicinal important herbs. If cannabis orchards are legalised for research work and medicinal purposes, then our state, Tripura also becomes economically and scientifically strong state in India. To inhibit a destruction another destruction is not the solution.

- A great part of our Indian economy is also connected to drugs. A large part of income of our country comes from profitable drug business. The Central Government and State Government give the licences of bars, shops involve in alcohol and drug business although the Narcotic Drugs and Psychotropic Substances Act of 1985 prohibits the production, sale and consumption of cannabis and other drugs. To reach Tripura in the "addiction free state", the State Government must disapprove the licences for bar and shops dealing with alcohol and drugs. The State Government will identify the dishonest businessmen, cancel their business licences and punish with imprisonment, fine or both.

- Our Central and State Governments construct a new education system for children and youths of schools, colleges and universities based on Indian ancient religion, Law, Science and Technology which induces the good and bad thinking in them on any issue like drug that move the present and future of India as well as any state like Tripura in a strong, joyful, developed destination instead of devastating destination.

\section{Conclusion}

In India, during different religious and social ceremonies like Mahashivratri, holy, ganja and bhang are used from ancient period. The most common picture of holy places of Tripura like Matabari, Unakuti, temple of Chaddadevata, Kasba Kalibari and others as well as India is the smoking of ganja by malted-long-haired saffron robed holy men. According to these holy men, ganja is the "prasad" (edible thing which is distributed to people after worshiping god as a blessings of god) Lord Shiva. Cannabis becomes uninterrupted part of religion.

Despite goodness and close relation with divinities like lord Shiva and Buddha, majority of modern day consumers of cannabis, in absence of spiritual discipline and ritualistic maturity, have pulled roughly this holy stimulant into disgrace. Man lost paradise when he gained the knowledge. If the people of anywhere like Tripura realize the realities of this small human life that no one can escape from the natural characteristics of human life, aging, disease and death then nobody in this earth waste his/her wealth, family as well as life by entering the materialistic world of drug for fake joy and relaxation. Then human will use drugs only for sake of life like medical purposes. Only, actual education provide proper knowledge to people of Tripura as well as India to use drugs for sake and development of mankind and society not for demolition. The availability and it's use must be controlled by all levels of governments and international. Without any hesitation, as a citizen of Tripura, I am appreciating our Chief Minister, Sri Biplab Kumar Dev for his deep fair thinking and proper steps for fulfilling his as well as state's vision "addiction free Tripura".

Hindu religion is a scientific religion. Our foods, rituals and ceremonies take birth from our religion and Hinduism can able to explain science behind these. According to our Vedas, Cannabis is one of five sacred Plant. Where Hinduism explained it's beneficial effects in human life, then only it's abuse by ignorant people cannot allow us to ignore it's beneficial effects for us. So, I, Dr. Tapasi Bhattacharjee appeal to our Central Government, Tripura Government and also our Chief Minister Sri Biplab Kumar Deb to think about it's beneficial effects on us, stop to destroying it and find path to use it for medicinal and research purposes and make a strong, scientifically and economically developed Tripura. Again, I, appeal to our Chief Minister and other Chief Ministers of other states of our country, "please save both young generation and cannabis".

\section{Bibliography}

1. McCain KR., et al. "Impaired Driving Associated with the Synthetic Cannabinoid 5f-Adb". Journal of Forensic Science and Criminology 6.1 (2018).

2. Alipour A., et al. "Review of the many faces of synthetic cannabinoid toxicities". Mental Health Clinician 9 (2019): 93-99.

3. Costiniuk CT., et al. "Oral cannabinoids in people living with HIV on effective antiretroviral therapy: CTN PT028-study protocol for a pilot randomised trial to assess safety, tolerability and effect on immune activation". BMJ Open 9.1 (2019): e024793. 
4. Preuss CV., et al. "Prescription of Controlled Substances: Benefits and Risks". StatPearls. StatPearls Publishing; Treasure Island (FL) (2019).

5. "Huge cache of Bangladesh-bound drugs seized in Tripura". Northeast now (2020).

6. Bradford A. "What is THC?" Livescience (2017).

7. Vuckovic S., et al. "Cannabinoids and pain: New insights from old molecules". Frontiers in Pharmacology (2018).

8. Holland K. "A Quick Take on Cannabis and Its Effects". Healthline (2018).

9. "Have you ever wondered why Lord Shiva is associated with weed?" Daily hunt (2018).

10. Buddy T. "The Different Forms of Marijuana". Verywellmind (2019).

11. Bhattacharyya., et al. "Opposite effects of delta-9- tetrahydrocannabinol and cannabidiol on human brain function and psychopathology". Neuropsychopharmacology 35.3 (2010): 764-774.

12. Jackson NJ., et al. "Impact of adolescent marijuana use on intelligence: Results from two longitudinal twin studies". Proceedings of the National Academy of Sciences of the United States of America 113.5 (2016): E500-E508.

13. Steigerwald S., et al. "Risks and Benefits of Marijuana Use: A National Survey of U.S. Adults". Annuals of International Medicine 169.5 (2018): 282-290.

14. State medical marijuana laws. NCSL. (2019).

15. May MB and Glode AE. "Dronabinol for chemotherapy-induced nausea and vomiting unresponsive to antiemetics". Cancer Management and Research 8 (2016): 49-55.

16. Rentsch P., et al. "Targeting the cannabinoid receptor CB2 in a mouse model of l-dopa induced dyskinesia". Neurobiology of Disease 134 (2019).

17. "National highways and their length". National Highways Authority of India (2012).

18. Deb D. "Biplab Deb's push for cannabis-free Tripura triggers exodus of farmers, they call for legalisation". The Indian Express (2018).

19. Bhaumik S. Tripura CM's Determined Push For Drugs-Free State Showing Results: Chief Minister Biplab Deb blames his Left predecessors for allowing Tripura to become a haven for drugs. Outlook India (2019).
20. Addiction and Stealing all over the state, drug peddler arrested. Dainik Sanbad (2020).

21. Nicholson J. "Causes of drug use among young people". Portland Community College (2019).

22. Saikia A. "In Tripura, a crackdown on cannabis cultivation leaves hundreds without livelihood: The government claims the crackdown is in line with its promise to make the state 'addiction free'". But residents say addiction wasn't a problem to begin with. 2018.

\section{Assets from publication with us}

- Prompt Acknowledgement after receiving the article

- Thorough Double blinded peer review

- Rapid Publication

- Issue of Publication Certificate

- High visibility of your Published work

Website: www.actascientific.com/

Submit Article: www.actascientific.com/submission.php

Email us: editor@actascientific.com

Contact us: +919182824667 